\section{A gene library that goes "moo"}

\section{Washington}

THEY are hardly rare and certainly far from exotic, but barnyard animals may soon be the next "endangered species" to get an international conservation programme.

The United Nation's Food and Agricultural Organization (FAO) is preparing to launch a five-year, \$15-million Global Animal Genetic Resources Programme that aims to rescue such unlikely animals as the Shiwal cow of Pakistan, the extraordinarily ugly Taihu pig of China and the stringy Fayoumi chicken of Egypt. Each is threatened not by predators or lost ecosystems, but by established Western breeds such as the Holstein cow and the factory chicken. Hoping to increase their output, farmers in developing countries are switching to high-productivity Western animals, abandoning native breeds that have been adapting to the local conditions for decades. FAO worries that if the local breeds are allowed to disappear, their diseaseresistance traits and ability to withstand harsh conditions may be lost, too.

Although Western farm animals generally produce more milk, eggs or offspring than the hardened stock of Africa, Asia and Latin America, experience has shown that there is nothing like an epidemic or a heat wave to remind local farmers why the old breeds have been around for so long. The Chinese Taihu pig may not grow to the size of a typical Western sow, but it can live on cabbage if need be.

This week, E. Patrick Cunningham, director of the FAO's animal production and health division, met officials of the World Bank in Washington, hoping to have the animal genetic resource programme included in the World Bank's $\$ 1,300$ million Global Environment Facility programme, which was established last year to promote conservation and protection efforts around the world. Although there are many current efforts to protect the genetic resource of agricultural plants - a more threatened group than the animals because of the ease in which seeds can be exchanged - the FAO project is one of the first to target livestock.

The first priority, says Cunningham, will be to find out what now exists. FAO is building a database of livestock breeds, including such data as the kind of farming conditions in which they are used and their birthing intervals. This, it turns out, is not always as easy as it sounds. "There are countries where all they can say is that 'there are sheep out there,"' he says.

Once the FAO researchers have the list in hand, they plan to identify the breeds most in danger of extinction. The Kerry cow of Ireland, for instance, is now down to only 200 animals. Since the turn of the century, half of Europe's domestic breeds have been lost, and a third of the remaining 770 breeds are in danger of disappearing within the next two decades. In parts of the developing world, the situation may be as bad or worse.

The tropics are likely to be the most critical area. Because that is where human populations are growing fastest, tropical farmers are under the greatest pressure to improve production. Switching to a highoutput Holstein may help for the moment, but FOA is worried about the possibility of disease or drought; pathogens are being spawned as fast as people in that part of the world. Researchers say that it is only a matter of time before one of them emerges to wipe out the Western stock. By then, the disease-resistant traits of some once-local breed may have already been lost.

FAO proposes to use about a dozen species - including the Barbados Blackbelly sheep, the N'Dama cattle of West

\section{London}

A DRAFT European Communities (EC) directive that would endorse the patenting of transgenic animals has finally cleared its most important hurdle. After nearly three years of inactivity, the European Parliament's legal affairs committee has decided that the 'inventors' of transgenic animals should be able file patents in the EC. European Commission biotechnology officials believe that the directive, first proposed in 1988, will now be adopted by ministers from the EC member states before the end of 1993 .

The directive has been controversial since its inception, attacked by the European Green movement and animal rights groups, who argue that many transgenic animals, particularly those produced for commercial gain, are likely to suffer. Patent Concern, a coalition formed specifically to oppose the directive, promises to continue the fight. But Willi Rothley, the German Social Democrat Member of the European Parliament who wrote the legal committee's report on the directive, believes the full parliament - which votes in February — will back his committee's position "by a large majority".

Ironically, the protracted delays in the parliament may have worked to the directive's advantage: two years ago, opinion about the wisdom of allowing animal patents was sharply divided. But now that the European Patent Office (EPO) has decided to grant a patent for Harvard University's transgenic 'oncomouse' (see Nature 353, 589; 1991), the political climate has changed. An EC decision to ban
Africa and the South American Criollo cattle - as trial projects in field preservation. Other endangered breeds would be added as they are identified.

DNA 'fingerprinting' of rare breeds can indicate which are distinct enough from more common stock to merit preservation. And as geneticists continue to identify disease genes, it may soon be possible to find out which breeds have the most valuable resistance traits. "We have no illusion," says Cunningham, "that this kind of money will allow us to do even a pale shadow of the genome project [the international effort to map human DNA]. But we want to steer and stimulate the people who are already doing this" to bring some attention to agricultural animals. Several groups - including those at the Indian Veterinary Research Institute, the University of Brisbane and Texas A\&M University - are already investigating livestock genetic resources. FAO hopes to get more researchers to join them down on the farm.

Christopher Anderson

\title{
Progress on animal patents
}

animal patents would now place the eight EC member states that have also signed the EPO's charter, the European Patent Convention, in a tricky legal position.

Although the parliament's legal committee rejected Patent Concern's call to ban animal patents, two amendments drafted by Rothley would place some restrictions on patenting. Chimaeras (animals produced by combining cells from two or more species into a single embryo) and genetic modifications that cause "unnecessary suffering...or physical harm" should not be patentable, the legal committee decided.

European Commission patent experts are worried that Rothley's wording would exclude Harvard's oncomouse, which is genetically engineered to develop tumours. The oncomouse clearly suffers physical harm, but is a useful tool in cancer research. Commission officials want to avoid inconsistency between the EC directive and EPO's decision, and say the amendments will have to be changed, after the directive leaves the parliament in February. But the changes are not expected to cause serious problems: the next time the parliament votes on the directive, it can register its disapproval only by rejecting the directive outright. This is considered unlikely, as the directive also contains a number of measures to improve patent protection for the European biotechnology industry that command widespread support. And in any case, Rothley says that his amendments are not designed to make the oncomouse patent illegal within the EC.

Peter Aldhous 